\title{
Purification and Characterization of Lipase from Aspergillus flavus PW2961 using Magnetic Nanoparticles.
}

\author{
Kareem, S. 0. ${ }^{1}$, Adebayo, O. S. ${ }^{1}$, Balogun, S. A. ${ }^{1}$, Adeogun, A. I. ${ }^{2}$ and \\ Akinde, S. B. ${ }^{3}$
}

${ }^{1}$ Department of Microbiology, Federal University of Agriculture, Abeokuta, P.M.B. 2240, Ogun State, Nigeria. ${ }^{2}$ Department of Chemistry, Federal University of Agriculture, Abeokuta, P.M.B. 2240, Ogun

State, Nigeria. ${ }^{3}$ Department of Biological Sciences, Osun State University, Osogbo, Osun State, Nigeria.

\begin{abstract}
Lipase from Aspergillus flavus was purified in a single step purification using $\mathrm{MnFeO}_{4}$ magnetic nano particles to achieve a 20.53- fold purification with specific activity of $11.29 \mathrm{U} / \mathrm{mg}$ and a $59 \%$ recovery yield. SDS-PAGE of lipase showed a single pure band with corresponding molecular weight of $35 \mathrm{kDa}$. The optimal temperature and $\mathrm{pH}$ for the enzyme activity were $45^{\circ} \mathrm{C}$ and 7.0 respectively. Addition of olive oil $(1 \% \mathrm{w} / \mathrm{v})$ enhanced pH stability of the lipase with $86 \%$ residual activity at pH 7.0 after $6 \mathrm{~h}$ of incubation while the lipase was thermostable with $79 \%$ residual activity after $4 \mathrm{~h}$ of incubation. The enzyme activity was enhanced by $\mathrm{Ca}^{2+}, \mathrm{Mg}^{2+}$ and $\mathrm{Mn}^{2+}$ while the presence of $\mathrm{Cu}^{2+}, \mathrm{Co}^{2+}$ and $\mathrm{Zn}^{2+}$ exhibited inhibitory effect on the enzyme. The study therefore presented lipase from Aspergillus flavus PW2961 with potential in industrial and biotechnological application.
\end{abstract}

(Received: 08:03:2017; Accepted: 05:04:2017)

Key words: Lipase, purification, Aspergillus flavus PW2961, magnetic nanoparticles. Correspondence: sharafkareem@yahoo.co.uk

\section{Introduction}

Lipases (EC 3.1.1.3) are enzymes capable of catalyzing the hydrolysis of fatty acids and glycerol into its monomeric units (Sharma et. al., 2001). Lipases are produced by many microorganisms and higher eukaryotes (Kamimura et. al., 2001). The ease with which enzymes could be isolated from microbes has made both bacteria and fungi predominant sources of lipase. However, fungi has been found to be the best lipase producers and are preferably used for various industrial purposes (Mahadik et. al., 2002). The most prospective lipase producers are found in the genera of Aspergillus, Rhizopus, Penicillium and Trichoderma (Kashmiri et. al., 2006).

Enzyme-catalysed reactions usually take place under relatively mild conditions, which make them ideal alternatives to various traditional chemical reactions. However, free enzymes usually have poor stability towards
$\mathrm{pH}$, heat or other factors and are difficult to recover and reuse (Kim et. al., 2006). Therefore, there is a great demand for ways of improving enzyme stability. Purification techniques, as a very powerful tool, have been intensively utilized to prepare various highperformance and economically-feasible biocatalysts with improved stability. Purification of enzymes using ammonium sulphate precipitation requires a lengthy separation period of about 12- $16 \mathrm{~h}$ for product recovery which often results in protein denaturation while the use of gel chromatography is slow and costly for developing economies (Kareem and Akpan, 2003).

There is a significant research interest in magnetic nanoparticles, as they offer a large spectrum of applications arising from their thermal, chemical, electrical, and magnetic field properties (Gu et. al., 2006, Wang et. al., 2007). 
Magnetic nanoparticles are known to have multiple applications in the field of separation and purification technology (Yavuz et. al., 2009). One of the most important characteristics of these nanoparticles is to have a large volume of surface area (the smaller the size of the particle the larger the surface area) which leads to high binding capacity for the ligands. (Dios and Díaz-García, 2010). In this paper, lipase from Aspergillus flavus was purified using magnetic nanoparticles (MNPs).

\section{Materials and Methods \\ Microrganism}

Strains of Aspergillus flavus were obtained from Culture Collection Unit of the Department of Microbiology, Federal University of Agriculture, Abeokuta, Nigeria. The isolates were sub-cultured on Potato Dextrose Agar (PDA) plates and preserved on PDA slant at $4^{\circ} \mathrm{C}$ temperature (Balogun and Fagade, 2010).

\section{Preparation of spore suspension}

Spore suspension of Aspergillus flavus was prepared by scrapping $1 \mathrm{~g}$ of the spore from the petri dish into $10 \mathrm{ml}$ of sterile distilled water (Kareem and Akpan, 2003) and then filtered using a sterile filter paper (Whatman, $125 \mathrm{~mm}$ ). The filtrate was used as source of inoculum for the solid state fermentation.

\section{Screening for lipase activity}

Phenol red agar plates were prepared using phenol red $(0.01 \% \mathrm{w} / \mathrm{v})$ along with $1 \%$ $(\mathrm{v} / \mathrm{v})$ olive oil, $0.1 \%(\mathrm{w} / \mathrm{v}) \mathrm{CaCl}_{2}, 2 \%(\mathrm{w} / \mathrm{v})$ agar, two drops of tween-20 and the $\mathrm{pH}$ was adjusted to 7.2 (Singh et. al., 2006). A loopful spore of Aspergillus flavus was inoculated on the agar plates and incubated for $28^{\circ} \mathrm{C}$ for 48 h. A change in color of phenol red from red to orange was used as an indicator of the lipase activity.

\section{Production of Lipase}

Production medium contained the following in percentage weight volume: rice bran 2.0, peptone $0.2, \mathrm{NH}_{4} \mathrm{H}_{2} \mathrm{PO} 40.1, \mathrm{NaCl}$ 0.25, $\mathrm{MgSO}_{4} \bullet 7 \mathrm{H}_{2} \mathrm{O} 0.04, \mathrm{CaCl}_{2} \cdot 2 \mathrm{H}_{2} \mathrm{O} \quad 0.04$, olive oil $2.0(\mathrm{v} / \mathrm{v})$ and 1-2 drops Tween 80 as emulsifier. The medium was adjusted to $\mathrm{pH}$ 7.0. After $72 \mathrm{~h}$ of incubation, the culture was centrifuged at $10,000 \mathrm{rpm}$ for $20 \mathrm{~min}$ at $4^{\circ} \mathrm{C}$ and the cell free culture supernatant was used as the source of lipase.

\section{Extraction of Lipase}

Lipase extraction was carried out using $2.5 \mathrm{ml}$ of $0.1 \mathrm{mM}$ sodium phosphate buffer ( $\mathrm{pH}$ 7.2) per gram of fermented medium (Couri et al., 2000). Crude enzyme extract was filtered using filter paper (Whatman, $125 \mathrm{~mm}$ ), centrifuged at $8000 \mathrm{rpm}$ for $20 \mathrm{~min}$ and the enzyme activity was determined.

\section{Determination of lipase activity}

Lipase activity was determined according to the method described by Sadasivam and Manikam (1996). A $250 \mathrm{ml}$ Erlenmeyer flask containing $2 \mathrm{ml}$ of $0.1 \mathrm{M}$ phosphorus buffer, $1 \mathrm{ml}$ of olive oil and $1 \mathrm{ml}$ of crude enzyme extract was incubated at $40^{\circ} \mathrm{C}$ for $30 \mathrm{~min}$. The reaction was stopped by the addition of $5 \mathrm{ml}$ of ethanol and then titrated against $0.1 \mathrm{~N} \mathrm{NaOH}$ using phenolphthalein as indicator. Appearance of pale pink color indicated the end point.

\section{Purification of lipase using magnetic nano - particles (MNPS)}

Purification of the enzyme (protein) was carried out using magnetic $\mathrm{MnFeO}_{4}$ nanoparticles MNPS ( $0.2 \mathrm{mg}$ size) as described by the method of Okoli et al., (2011). The magnetic $\mathrm{MnFeO}_{4}$ nanoparticles were washed three times each with $10 \mathrm{mmolL}^{-1}$ ammonium acetate buffer, $\mathrm{pH} 6.7$, to equilibrate the particles and then suspended in buffer. The MNPS was transferred into crude lipase solution $(10 \mathrm{ml})$ and incubated at $25^{\circ} \mathrm{C}$ in an orbitary shaker for $60 \mathrm{~min}$. The unbound protein was separated by applying an external magnetic field and regarded as purified enzyme. The bound protein was eluted with $0.8 \mathrm{M} \mathrm{NaCl}$ in ammonium acetate buffer.

\section{Protein determination}

Protein content was evaluated by the method of Lowry et. al. (1951) using bovine serum albumin as standard. All measurements were performed three times and the average value was taken.

\section{Effect of temperature on lipase activity}

Effect of temperature on lipase activity was determined between $25^{\circ} \mathrm{C}$ and $80^{\circ} \mathrm{C}$ using olive oil $(1 \% \mathrm{w} / \mathrm{v})$ in $0.1 \mathrm{M}$ sodium phosphate buffer ( $\mathrm{pH} 7.2)$ as the substrate.

\section{Effect of $\mathrm{pH}$ on lipase activity}

Effect of pH on enzyme activity was evaluated by carrying out the reactions in different buffers in $0.1 \mathrm{M}$ sodium acetate 
buffer ( $\mathrm{pH}$ 5- 5.5), $0.1 \mathrm{M}$ sodium phosphate buffer $(\mathrm{pH} 6.0-7.5)$ and $0.1 \mathrm{M}$ tris-glycerine buffer ( $\mathrm{pH} 8-9)$ at $60^{\circ} \mathrm{C}$ for $1 \mathrm{~h}$.

\section{Enzyme stability profile}

The thermostability of the purified lipase was determined by pre-incubating a solution of enzyme $(5 \mathrm{ml})$ for $6 \mathrm{~h}$ at various temperatures $\left(25-80^{\circ} \mathrm{C}\right)$, with or without olive oil $(1 \% \mathrm{w} / \mathrm{v})$. pH stability of the purified lipase was determined by mixing the enzyme solution with sodium phosphate buffer $(0.1 \mathrm{M})$ in a $\mathrm{pH}$ range (5-9) and kept at $30^{\circ} \mathrm{C}$ for $6 \mathrm{~h}$. The residual enzyme activity was determined at $30 \mathrm{~min}$ regular intervals.

\section{Effect of activators and inhibitors}

Effect of various metal ions $\left(\mathrm{Mn}^{+2}\right.$, $\mathrm{Co}^{+2}, \mathrm{Ca}^{+2}, \mathrm{Cu}^{+}, \mathrm{Zn}^{+2}$ and $\mathrm{Mg}^{+2}$ ) and $5 \mathrm{mM}$ ethylene diamine tetra acetic acid (EDTA) on enzyme activity was investigated on the purified lipase enzyme. A mixture containing $0.5 \mathrm{ml}$ of the metal ion solutions and $0.5 \mathrm{ml}$ of enzyme solution was incubated at $\mathrm{pH} 7.2$ for $30 \mathrm{~min}$ at room temperature. The relative enzyme activity was measured under standard assay.

Molecular weight determination using SDSpage analysis

The molecular weight of the enzyme (crude and purified extract) was determined in a $10 \%$ SDS PAGE mini gels stained with Coomassie brilliant blue to visualize the protein (Okoli, 2011).

\section{Results and Discussion}

Purification of crude lipase resulted in a 20.5- fold purification with a final yield of $59 \%$ of total lipase in a single-step purification procedure as shown in Table 1 . This purification fold is higher than previous report on a single step technique (Kareem and Akpan, 2003).

The result presented in Figure 1 indicated that the enzyme was active over a broad $\mathrm{pH}$ range (5.0- 9.0) with optimum activity at $\mathrm{pH}$ 7.0. This $\mathrm{pH}$ range was reported to offer wide industrial application (Romero et. al., 2007). This findings is similar to that reported by Kamini et. al., (1998) for lipase activity from Aspergillus niger MTCC 2594.

Lipase from fungi has been exploited as valuable industrial enzyme due to its stability profile (Gulati et. al., 2000). The effect of $\mathrm{pH}$ on the stability of lipase showed that the enzyme was more stable at $\mathrm{pH}$ values 7.0 - 8.0 while retaining substantial enzyme activities of $86 \%$ and $80 \%$ at pH values 7.0 and 8.0 respectively after $6 \mathrm{~h}$ of incubation (Fig.3). Most microbial lipases are stable in the $\mathrm{pH}$ range of 2 to 10.5 (Falony et. al., 2006). Similar results have been reported for other fungal lipases (Salleh et. al., 1996; Falony et. al., 2006). The result showed that lipase activity when incubated at $\mathrm{pH} 9$ for $1 \mathrm{~h}$, retained $80 \%$ relative activity suggesting its potential use in various biotechnological processes especially in detergency.

The optimum temperature of lipase from Aspergillus flavus from this findings is shown to be $45^{\circ} \mathrm{C}$ (Fig. 2), this is in agreement with the study of Thamaraichelvan et. al. (2010), who reported $45^{\circ} \mathrm{C}$ as the optimum temperature of lipase from Aspergillus niger. The enzyme was thermostable in the temperature range of 40 to $60^{\circ} \mathrm{C}$ (Figure 4) by retaining $91 \%, 86 \%$ and $79 \%$ residual activity respectively after $4 \mathrm{~h}$ incubation, these characteristics indicated that the lipase is a thermostable lipase. Thamaraichelvan et. al., (2010) showed that lipase from Aspergillus flavus exhibited maximum thermostability between $40^{\circ} \mathrm{C}$ and $60^{\circ} \mathrm{C}$ when incubated for 1 hr.

Most fungal lipases have low thermal stability and are unstable at temperatures above $40^{\circ} \mathrm{C}$ (Thamaraichelvan et. al., 2010). The enzyme reported in this study was found to be completely stable at $50^{\circ} \mathrm{C}$ after $1 \mathrm{~h}$. At $60^{\circ} \mathrm{C}$, the enzyme maintained $81 \%$ stability 1 $\mathrm{h}$ after the initial activity. The thermostable lipase will offer advantages in various biotechnological processes such as detergency, trans-esterification, wastewater treatment (Denise et. al., 2015). Among the metal ions tested, $\mathrm{Ca}^{2+}$ and $\mathrm{Mg}^{2+}$ enhanced lipase activity with $139 \%$ and $124 \%$ relative activity respectively when compared to the control (Figure 5). These ions have been reported as cofactor for lipase (Dong et. al., 1999). The results obtained from this study were in agreement with the report of Amal et. al. (2016) that lipase from Rhizopus oligosporus was activated by $\mathrm{Mn}^{2+} \mathrm{Ca}^{2+}$ and $\mathrm{Mg}^{2+}$. The hydrolytic activity of the enzyme was inhibited by heavy metals such as $\mathrm{Zn}^{2+}$, $\mathrm{Co}^{2+}$ and $\mathrm{Cu}^{2+}$ with $60 \%, 69 \%$ and $75 \%$ relative activity respectively, which suggests that metal ions may be interfering with enzyme activity by acting directly on enzyme active site (Supakdamrongkul et. al., 2010).

The purified lipase exhibited a single protein band with a molecular weight of 35 kDa (Figure 6). Similarly, lipase isoenzyme from an Aspergillus niger purified in a simple 
adsorption step with C8 modified magnetic particles was reported to show a single pure band with a molecular weight of $35 \mathrm{KDa}$ (Hernández-García et. al., 2014).

In conclusion, this study presented the potential of magnetic nanoparticles in the purification of crude lipase as a rapid, simple and efficient absorbent. The purified lipase produced by Aspergillus flavus was stable at alkaline $\mathrm{pH}$ and high temperature, therefore making it a potential candidate for industrial purposes.

Table 1: Summary of Purification of lipase from Aspergillus flavus PW2961

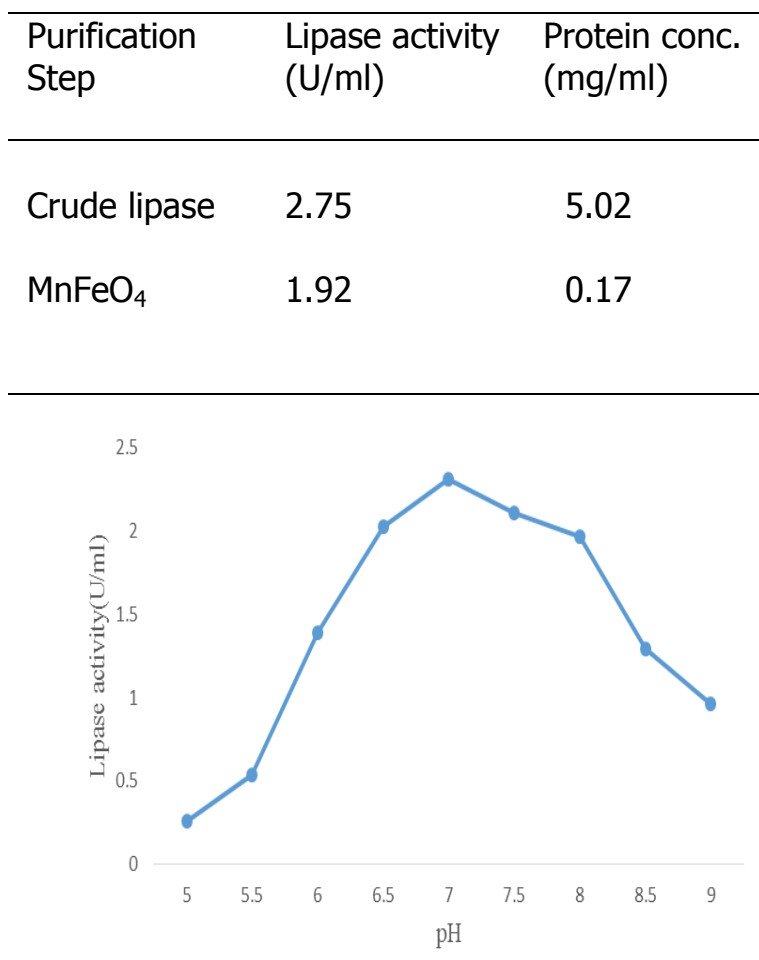

Figure 1: Effect of $\mathrm{pH}$ on lipase activity isolated from Aspergillus flavus

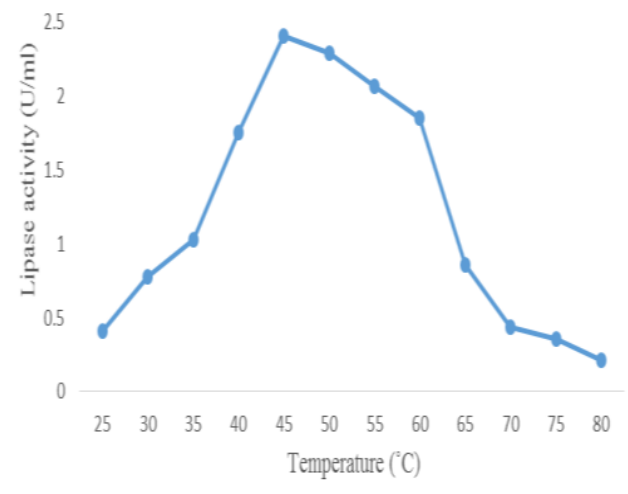

Figure 2: Effect of assay temperature of lipase activity from Aspergillus flavus PW2961

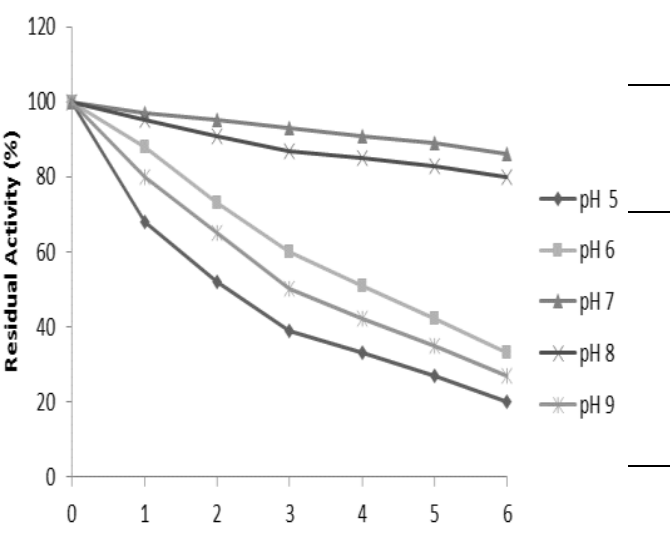

Figure 3: $\mathrm{pH}$ stability profile of lipase activity

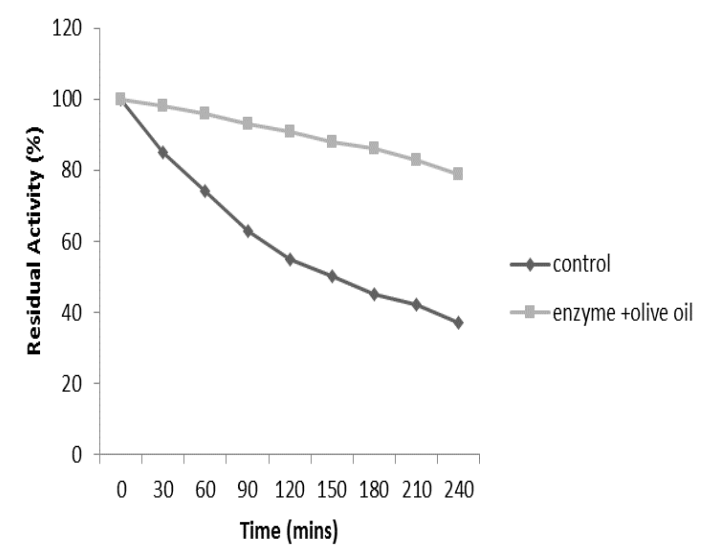

Figure 4: Thermostability profile of lipase activity from Aspergillus flavus

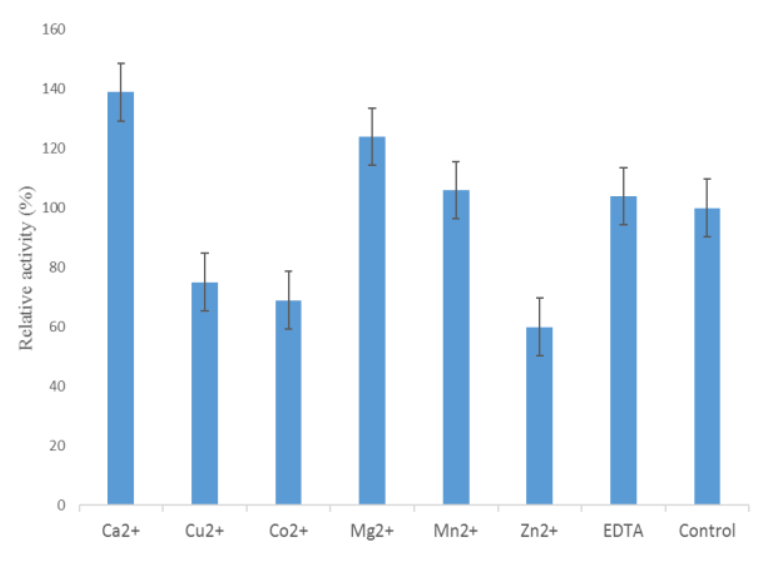

Figure 5: Effect of activators and inhibitors on purified lipase 


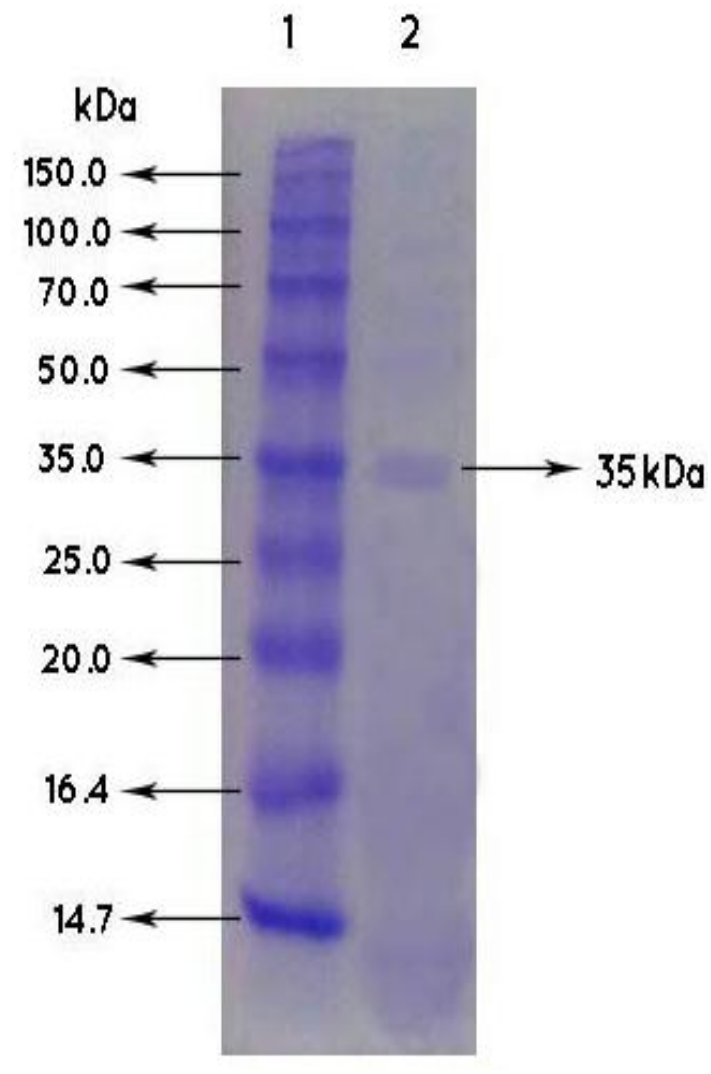

Figure 6: SDS-PAGE analysis of lipase from Aspergillus flavus PW2961. Lane 1-indicates molecular weight standard markers and Lane 2-shows purified lipase band of molecular weight approximately $35 \mathrm{kDa}$.

\section{References}

Amal, A., Elgharbawy, M.D., Zahangir, A. And Hamzah, M. S. (2016). Characterization of a low-cost lipase by solid-state Fermentation of palm kernel cake using Candida cylindracea. ARPN J. Eng. Appl. Sci. 11 (1): 432-438

Balogun, S. A. And Fagade, O. E. (2010). Emulsifying Bacteria in Produce Water from Niger-Delta, Nigeria. Afri. J. Microbiol Res. 4: 730-734.

Couri, S., Terzi, S., Da, C., Pinto, G.A.S., Freitas, S.P. And Costa, A.C.A. (2000). Hydrolytic enzyme production in solid state fermentation by Aspergillus niger 3T5B8. Process Biochem. 36: 255-261.

Denise, S., Lívia A. S., Jamil, S. O., Marcelo, M. S., Inayara, C. A., Gecernir, C. And Jacqueline, A. T. (2015). Colletotrichum gloeosporioides lipase: Characterization and use in hydrolysis and esterifications. Afr. J. Microbiol. Res. 9(19):1322-1330,

Dios, A. And Díaz-García, M.E. (2010). Multifunctional nanoparticles: Analytical prospects Analytica Chimica Acta 666, 1.

Dong, H., Gao, S., Han, S. And Cao, S. (1999). Purification and characterization of a Pseudomonas sp. Lipase and its properties in non-aqueous media. Biotechnol. Appl. 30: 251-256.

Falony, G., Armas, J.C., Mendoza, J.C.D. And Hernandez, J.L.M. (2006). Production of extracellular lipase from Aspergillus niger by solid state fermentation. Food Tech. Biotech. 44: 235- 240.

Gulati, R., Saxena, R.K. And Gupta, R. (2000). "Fermentation and downstream processing of lipase from Aspergillus terreus.". Process Biochem. 36: 149-155.

Gu, H.W., Xu, K.M., Xu, C.J. And Xu, B. (2006). Biofunctional magnetic nanoparticles for protein separation and pathogen detection. Chem. Commun. 10:941-946.

Hernández-García, S., García-García, M.I. and García-Carmona, F. (2014). Purification, Immobilization andCharacterization of Lipase Isoenzyme from Aspergillus niger with C8 Magnetic Particles. Adv. Biosci Biotech. 5: 633641.

Kamimura, E.S., Medieta, O., Rodrigues, M.I. And Maugeri, F. (2001). Studies on lipaseaffinity adsorption using response-surface analysis. Biotech. Appl. Biochem. 33(3): 153159.

Kamini, N.R. Mala, J.G.S. And Puvanakrishnan, R. (1998). Lipase production from Aspergillus niger by solid-state fermentation using gingelly oil cake, Process Biochem. 33 505-511.

Kareem, S.O. And Akpan, I. (2003). Clarification of Amylase from moldy bran with Imarsil, Enzyme Microbial. Tech. 33. 259-261.

Kashmiri, M.A., Ahmad, A., And Butt, B.W. (2006). Production, purification and partial characterization of lipase from Trichoderma viride. Afri. J.Biotech. 5(10): 878-882.

Kim, J., Gratea, J.W. And Wang, P. (2006). Nanostructures for enzyme stabilization. Chem. Eng. Sci. 61:1017-1026. 
Lowry, O.H., Rosebrough, N.J., Farr, A.L. And Randall, R.J. (1951). Protein measurement with folin phenol reagent. J.Biol. Chem. 193: 265-275.

Mahadik, N.D., Puntambekar, U.S., Bastawde, K.B., Khire, J.M. And Gokhale, D.V. (2002). Production of acidic lipase by Aspergillus niger in solid state fermentation. Process Biochem. 38(5): 715-721.

Okoli, C., Boutonnet, M., Mariey, L., Jaras, S. And Rajarao, G. (2011). Application of magnetic iron oxide nanoparticles prepared from microemulsions for protein purification. J. Chem. Tech. Biol. 86: 1386-1393.

Okoli, C. (2011). Characterization of superparamagnetic iron oxide nanoparticles and its application in protein purification. J. of Nanosci Nanotech. 11: 10201-10206.

Romero, C.M., Baigori, M.D. and Pera, L.M. (2007). Catalytic Properties of MyceliumBound Lipases from Aspergillus niger MYA 135. Appl. Microbiol. Biotech. 76: 861-866.

Sadasivam, S. And Manickam, A. (1996). Biochemical methods, new age international limited, publishers, second edition, New Age International (p) Ltd. Publisher, New Delhi, pp 179-186

Salleh, A.B., Razak, C.N.A., Samad, M.Y.A, Ampol, K., Yunus, W.M.Z. And Basri, M. (1996). Partial purification and characterization of lipases from thermophilic Rhizopus rhizopodiformis. Sains Malay. 25:131- 141.

Sharma, R., Chisti, Y. And Banerjee, U.C. (2001). Production, purification, characterization, and applications of lipases. Biotech. Adv. 19(8): 627-629.

Singh, R., Gupta, N., Goswami, V.K. And Gupta, R. (2006). A simple activity staining protocol for lipases and esterases. Appl. Microbiol. Biotechnol. 70: 679-682.

Supakdamrongkul, P., Bhumiratana, A. And Wiwat, C. (2010). Characterization of an extracellular lipase from the biocontrol fungus Nomuraea rileyi MJ, and its toxicity toward Spodoptera litura. J. Invertebr. Pathol. 105:228-235.

Thamaraichelvan, R., Muthusamy, P., Chidambaram, K.V., Krishnan, N. And Paulraj. J. (2010). Production, partial purification and characterization of Lipase from Aspergillus flavus KUF108. Pak. J. Sci. Ind. Res. 53(5): 258-264.

Wang, W., Deng, L., Peng, Z.H. And Xiao, X. (2007). Study of the epoxydized magnetic hydroxyl particles as a carrier for immobilizing penicillin G acylase. Enzyme Microb.Technol.40, 255-259

Yavuz, C.T., Prakashb, A., Mayoa, J.T. And Colvin, V.L. (2009). Magnetic separations: From steel plants to biotechnology. Chem Eng. Sci 64: 2510- 2516 